\title{
SOSIALISASI PENTINGNYA LEGALITAS FORMAL DALAM KEPEMILIKAN TANAH DI DESA SENTELUK KECAMATAN BATU LAYAR KABUPATEN LOMBOK BARAT
}

\section{Socialization Of The Importance Of Formal Legality In Land Ownership In Senteluk Village, Batu Layar Sub-District, West Lombok District}

Arief Rahman, Wiwiek Wahyuningsih, Shinta Andriyani, Diman Ade Mulada

Program Studi Ilmu Hukum Universitas Mataram

Jalan Majapahit No.62 Kota Mataram, Provinsi Nusa Tenggara Barat

*Alamat korespondensi : ariefrahman@unram.ac.id

(Tanggal Submission: 10 Maret 2021, Tanggal Accepted : 17 April 2021)

\section{Keyword : Abstract :}

Legalitas

Belum adanya bukti kepemilikan tanah (sertifikat) terhadap suatu hak atas tanah Formal; Hak menyebabkan belum terwujudnya tertib hukum dan tertib administrasi sehingga Atas Tanah hal ini dapat memicu terjadinya sengketa hak atas tanah. Masyarakat kurang memahami arti pentingnya melakukan legalitas formal terkait dengan kepemilikan tanah, hal ini mengakibatkan sering terjadi sengketa hak atas tanah, sebagai akibat dari tidak dilakukannya kegiatan legalits formal terhadap tanah yang ia miliki sebagaimana yang diatur dalam ketentuan peraturan perundang-undangan yang beralaku. Kegiatan pengabdian kepada masyarkat ini bertujuan untuk mensosialisasikan pentingnya legaitas formal dalam kepemilikan tanah. Metode yang digunakan dalam penyuluhan ini adalah metode ceramah dan diskusi. Dalam kegiatan ini, jumlah peserta yang mengikuti kegiatan sosialisasi tidak begitu banyak karena kondisi pandemi covid 19. Pelaksanaan kegiatan penyuluhan hukum berjalan dengan tertib, aman dan lancar serta sesuai dengan protokol kesehatan. Para peserta penyuluhan hukum mengikuti kegiatan dengan rasa antusiasme yang tinggi, hal ini terlihat dari keaktifan mereka dalam mengajukan sejumlah pertanyaan-pertanyaan dan kasus-kasus hukum yang mereka hadapi kepada tim penyuluh terutama yang terkait dengan legalitas formal kepemilikan hak atas tanah. Sehingga dengan dilakukannya kegiatan sosialisasi tersebut dapat menambah informasi, merubah pola pikir dan sikap masyarakat Desa Senteluk akan pentingnya melakukan kegiatan legalitas formal terhadap hak atas tanah yang dimilikinya.

Panduan sitasi / Citation guidance (APPA $7^{\text {th }}$ edition) :

Rahman, A., Wahyuningsih, W., Andriyani, S., \& Mulada, D. A. (2021). Sosialisasi Pentingnya Legalitas Formal Dalam Kepemilikan Tanah Di Desa Senteluk Kecamatan Batu Layar Kabupaten Lombok Barat. Jurnal Abdi Insani Universitas Mataram, 8 (1), 100-110. http://doi.org/10.29303/abdiinsani.v8i1.382. 


\section{PENDAHULUAN}

Kebijakan dasar pembangunan nasional tertuang dalam Pembukaan Undang-Undang Dasar 1945, yaitu melindungi segenap bangsa dan seluruh tumpah darah Indonesia, memajukan kesejahteraan umum, mencerdaskan kehidupan bangsa dan ikut melaksanakan ketertiban dunia yang berdasarkan kemerdekaan, perdamaian abadi, dan keadilan sosial. Dari sekian sektor pembangunan, kebijakan terhadap legalitas formal tanah menjadi bagian yang sangat penting bagi masyarakat yang membutuhkan kepastian hukum terhadap tanahnya.

Tanah sebagai karunia dari Tuhan Yang Maha Esa merupakan sumber daya alam yang sangat diperlukan oleh manusia, seperti cocok tanam, tempat tinggal, maupun untuk melakukan usaha. Begitu bernilainya tanah sehingga manusia yang merupakan makhluk social akan mempertahankan tanahnya dengan cara apapun. Sebagai sumber kehidupan, keberadaan tanah dalam kehidupan mempunyai arti dan sekaligus memiliki fungsi ganda, yaitu sebagai social asset dan capital asset. Sebagai socialasset tanah merupakan sarana pengikat kesatuan sosial di kalangan masyarakat Indonesia dalam hidup bermasyarakat, sedangkan capital asset, tanah merupakan faktor modal dalam pembangunan dan tanah harus dipergunakan dan dimanfaatkan sebesar-sebesarnya untuk kesejahteraan rakyat secara adil dan merata, juga harus dijaga kelestariannya (Setiabudi, 2013).

Seirimg dengan perubahan dan perkembangan pola pikir, pola hidup dan kehidupan manusia, maka dalam soal mengenai tanah juga terjadi perubahan terutama berkaitan dengan kepemilikan dan penguasaannya, mengenai kepastian hukum dan kepastian hak atas tanah yang sedang atau akan dimilikinya. Dalam undang-Undang Dasar 1945, telah menegaskan bahwa Negara Indonesia merupakan Negara yang berdasarkan atas hukum (rechstaat) dan tidak berdasarkan atas kekuasaan belaka (machstaat). Demikian pula soal tanah, pemerintah berkewajiban memberikan kepastian hukum terhadap status tanah yang dikuasai masyarakat atau badan usaha.

Untuk memperoleh kepastian hukum dan kepastian akan hak atas tanah Undang-Undang Agraria No. 5 Tahun 1960 telah meletakkan kewajiban kepada Pemerintah untuk melaksanakan legalitas formal terhadap tanah (pendaftaran tanah) yang ada di seluruh Indonesia, disamping bagi pemegang hak untuk mendaftarkan hak atas tanah yang ada padanya sesuai dengan ketentuan yang berlaku (Prakosa dan Purwanto, 1985). Terkait dengan kewajiban pemerintah untuk melaksanakan legalitas formal terhadap tanah (pendaftaran tanah) diatur dalam pasal 19 UUPA. Untuk melaksankan legalitas formal terhadap tanah (pendaftaran tanah) sebagaimana maksud Pasal 19 UUPA, maka Pemerintah mengeluarkan Peraturan Pemerintah Nomor 10 Tahun 1961 tentang Pendaftaran Tanah. Peraturan Pemerintah Nomor 10 Tahun 1961 tersebut membuka sejarah baru dalam hukum agraria. Sebab, untuk pertama kali Indonesia mempunyai suatu lembaga yang secara khusus mengatur tentang pelaksanaan pendaftaran tanah. Namun lebih kurang 36 tahun setelah berlakunya Peraturan Pemerintah Nomor 10 Tahun 1961 ternyata upaya pemerintah dalam memberikan jaminan kepastian hukum atas tanah belum optimal, sehingga pemerintah merasa perlu untuk menyempurnakan dan menggantikan dengan suatu peraturan baru sehingga eksistensi Peraturan Pemerintah Nomor 10 Tahun 1961 sudah direvisi atau dilakukan pengkajian ulang dari persoalan yang sangat mendasar.

Upaya dari perubahan tersebut dilakukan Pemerintah dengan dikeluarkannya suatu peraturan baru yaitu Peraturan Pemerintah Nomor 24 Tahun 1997 yang berlaku tanggal 8 Oktober 1997 tentang Pendaftaran Tanah. Peraturan Pemerintah No. 24 Tahun 1997 merupakan realisasi Pemerintah dalam melakukan penyederhanaan pola pendaftaran tanah di Indonesia (Harsono, 2003). Dalam Peraturan Pemerintah Nomor 24 tahun 1997 Pasal 1 yang dimaksud dengan pendaftaran tanah adalah rangakaian kegiatan yang dillakukan oleh pemerintah secara terus menerus, berkesinambungan dan teratur meliputi pengumpulan, pengolahan, pembukuan dan pengkajian serta pemeliharaan data fisik dan data yuridis dalam bentuk peta dan daftar mengenai bidang-bidang tanah dan satuan-satuan rumah susun, termasuk pemberian surat bukti haknya bagi bidang -bidang tanah yang sudah ada haknya dan hak milik atas satuan rumah susun serta hak-hak tertentu yang membebaninya. Pendaftaran tanah dilakukan oleh setiap orang yang berkepentingan atas suatu tanah. Tanah yang sudah didaftarkan akan menghasilkan suatu produk akhir yaitu berupa sertipikat sebagai tanda bukti kepemilikan hak atas tanah (Soerodjo, 2002). 
Namun dalam kenyataannya masyarakat masih belum memahami pentingnya melakukan legalitas formal terkait dengan kepemilikan tanah yang disebabkan karena tingkat kesadaran hukum masyarakat pada umumnya masih rendah dan adanya anggapan bahwa proses melakukan legalitas formal terkait dengan kepemilikan tanah memerlukan biaya yang banyak serta prosedurnya dianggap rumit. Dengan mengingat hal-hal diatas maka tim penyuluh merasa perlu untuk melakukan kegiatan sosialisasi (penyuluhan hukum) dalam bidang hukum pertanahan terutama yang berkaitan dengan meningkatkan kesadaran hukum masyarakat akan pentingnya melakukan legalitas formal terkait dengan kepemilikan tanah.

\section{METODE PELAKSANAAN}

Dalam rangka pelaksanaan kegiatan penyuluhan hukum di Desa Senteluk, Kecamatan Batulayar, Kabupaten Lombok Barat, langkah awal yang dilakukan oleh tim penyuluh adalah mengadakan komunikasi dengan kepala desa dan stafnya mengenai rencana kegiatan penyuluhan hukum tersebut. Setelah mendapatkan persetujuan atau izin untuk menyelengarakan kegiatan penyuluhan maka kemudian tim penyuluh menentukan waktu pelaksanaan penyuluhan hukum dan kemudian melaksanakan kegiatan penyuluhan hukum. Adapun khalayak yang menjadi sasaran penyuluhan hukum adalah para pemilik/pemegang hak atas tanah yang belum melakukan legalitas formal atas kepemilikan hak atas tanah dengan tujuan menumbuhkan kesadaran masyarakat mengenai pentingnya melakukan legalitas formal terhadap tanah yang mereka miliki.. Selain itu juga yang menjadi sasaran kegiatan ini adalah para tokoh agama, tokoh pemuda, tokoh masyarakat daan anggota masyarakat lainnya. Metode yang digunakan dalam penyuluhan hukum ini adalah metode ceramah dan diskusi. Metode Ceramah digunakan untuk memberikan pemahaman kepada para peserta tentang topik pengabdian legalitas formal (pendaftaran tanah) terkait dengan kepemilikan tanah. Dalam ceramah diuraikan mengenai materi legalitas formal terkait dengan kepemilikan tanah secara jelas, sistemasis sehingga mudah dipahami. Sedangkan metode diskusi digunakan untuk lebih memberikan kesempatan kepada para peserta membahas, mempertanyakan, menggaris bawahi, memberi masukan, dan atau memperdalam materi yang diceramahkan (Marwa dan Dinata, 2020).

\section{HASIL DAN PEMBAHASAN}

Kegiatan sosialisasi (penyuluhan hukum) dilaksanakan pada hari Jumat, 4 Septemberr 2020, di Desa Senteluk, Kecamatan Batulayar, Kabupaten Lombok Barat dengan jumlah peserta yang tidak begitu banyak karena kondisi pandemi covid 19. Pelaksanaan kegiatan penyuluhan hukum berjalan dengan tertib, aman dan lancar serta sesuai dengan protokol kesehatan. Para peserta penyuluhan nampaknya sangat antusias sekali mengikuti sajian materi yang disampaikan oleh tim mengenai pentingnya melakukan legalitas formal terkait dengan kepemilikan tanah. Materi penyuluhan hukum ini sangat dirasakan bermanfaat sekali oleh masyarakat, sebab materi utama yang di sampaikan adalah pentingnya melakukan kegiatan legalitas formal mengenai kepemilikan hak atas tanah. Karena seperti yang kita ketahui bersama sampai saat ini masih banyak masyarakat, khususnya yang berada di daerah pedesaan belum melakukan legalitas formal terhadap bidang tanah yang dimilikinya.

Faktor-faktor penghambat yang ditemui yang meskipun faktor itu tidak merupakan kendala dalam pelaksanaan penyuluhan hukum ini adalah antara lain:

1. Sulit menentukan waktu yang tepat untuk mengumpulkan orang-orang, karena masih dalam masa pandemi covid 19.

2. Adanya terdapat beberapa peserta yang tidak bisa berbahasa indonesia, tetapi hal itu tidaklah menjadi persoalan karena dari anggota tim penyuluh ada yang bisa berbahasa daerah (bahasa sasak) sehingga materi penyuluhan bisa dijelasakan dengan bahasa sasak untuk mudah dipahami oleh peserta. 


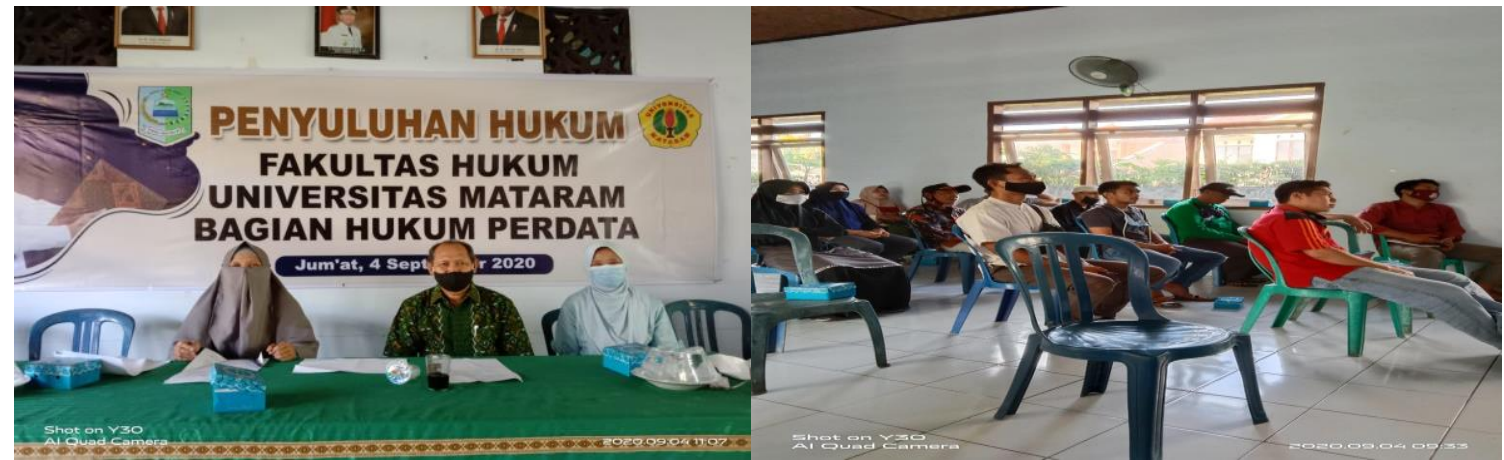

Gambar 1. Tim Pelaksana dan Peserta Kegiatan

Adapun beberapa materi yang disampaikan oleh tim penyuluh, antara lain mengenai:, Kepemilikan Hak Atas Tanah, Legalitas Formal Kepemilikan Hak Atas Tanah dan Sertifikat Sebagai Bukti Legalitas Formal Hak Atas Tanah. Berikut penjelasan beberapa materi yang disampaiakan oleh tim penyuluh:

\section{Kepemilikan Hak Atas Tanah}

Tanah sebagai sumber daya alam merupakan karunia Tuhan Yang Maha Esa kepada bangsa Indonesia. Oleh karena itu sudah sewajarnya apabila kita mengelola tanah dengan sebaik-baiknya agar pemanfaatannya dapat memberikan kemakmuran rakyat sebagaimana diamanatkan dalam Pasal 33 ayat (3) Undang- Undang Dasar 1945 (Hutagalung, 2005).

Tanah dalam terminology asing disebut dengan Land, Soil (Inggris), Adama (Semit) dan dalam beberapa terminology daerah disebut dengan Siti, Bumi, Lemah (Jawa); Pelemahan (Bali), Taneuh, leumah (Sunda); Petak, Bumi (Dayak); Rai (Tetum). Perbedaan istilah terjaadi bukan sekedar karena adanya perbedaan bahasa, namun lebih dari itu karena perbedaan pemaknaan tanah oleh manusia yang menguasai atau menggunakannya. Tanah dalam arti hukum memiliki peranan yang sangat penting dalam kehidupan manusia karena dapat menentukan keberadaan dan kelangsungan hubungan dan perbuatan hukum, baik dari segi individu maupun dampak bagi orang lain. Untuk mencegah masalah tanah tidak sampai menimbulkan konflik kepentingan dalam masyarakat, diperlukan pengaturan, penguasaan dan penggunaan tanah atau dengan kata lain disebut dengan hukum tanah.

Kebijakan penggunaan tanah di Indonesia dituangkan dalam Pasal 2 Ayat (3) Undang-Undang Nomor 5 Tahun 1960, bahwa tanah itu harus digunakan untuk sebesar-besarnya kemakmuran rakyat dengan berencana sesuai dengan Pasal 14 dan adanya kewajiban untuk memelihara dan menambah kesuburan tanah yang dipergunakan tersebut. Pada pasal 33 (1) UUD 1945, dikatakan bahwa "bumi air dan ruang angkasa, termasuk kekayaan alam yang terkandung di dalamnya itu pada tingkatan tertinggi dikuasai oleh Negara". Negara sebagai organisasi kekuasaan seluruh rakyat. Hak menguasai dari negara termasuk dalam UUPA Pasal 1 ayat (2) memberi wewenang kepada negara untuk: mengatur dan menyelenggarakan peruntukan, penggunaan, persediaan dan mengatur hubunganhubungan hukum antara orang-orang dengan bumi, air dan ruang angkasa; menentukan dan mengatur hubungan hukum antara orang-orang dan perbuatan-perbuatan hukum yang mengenai bumi, air dan ruang angkasa. "Hak" pada hakekatnya adalah kekuasaan yang diberikan oleh hukum kepada Seseorang terhadap sesuatu (benda/prestasi), sehingga menimbulkan hubungan hukum antara keduanya (hubungan subjek objek).

Pasal 4 ayat (1) UUPA Menjelaskan bahwa Atas dasar hak menguasai dari Negara sebagai yang dimaksud dalam Pasal 2 ditentukan adanya macam-macam hak atas permukaan bumi, yang disebut tanah, yang dapat diberikan kepada dan dipunyai oleh orang-orang baik sendiri maupun bersamasama dengan orang lain serta badan-badan hukum. Hak atas tanah adalah hak yang memberi wewenang kepada seseorang yang mempunyai hak untuk mempergunakan atau mengambil manfaat atas tanah tersebut. Dalam Undang-Undang Nomor 5 Tahun 1960 Tentang Peraturan Dasar PokokPokok Agraria, pada pasal 4 ayat (1) dan (2) mengemukakan bahwa atas dasar hak menguasai dari 
Negara ditentukan adanya macam-macam hak atas tanah, yang dapat diberikan kepada perorangan, kelompok maupun badan hukum, dimana hak atas tanah ini memberikan wewenang untuk memanfaatkan dan mempergunakannya yang langsung berhubungan dengan tanah itu, dengan batasan UUPA dan peraturan-peraturan yang lebih tinggi lainnya. Hak atas tanah merupakan hak dasar yang sangat berarti bagi masyarakat untuk harkat dan kebebasan diri seseorang. Di sisi lain, adalah kewajiban negara memberikan jaminan kepastian hukum terhadap hak atas tanah itu walaupun hak tersebut tetap dibatasi oleh kepentingan orang lain, masyarakat, dan terlebih lagi negara (Dewandaru et al., 2020). Berikut macam-macam hak atas tanah, yaitu:

\section{Hak Milik}

Hak milik sebagai salah satu hak yang melekat dalam benda menjadikannya selalu jadi kajian yang serius dalam penentuan dan pembentukan pokok-pokok hak suatu benda. Hak milik adalah hak turun temurun, terkuat dan terpenuh yang dapat dipunyai orang atau badan hukum atas tanah dengan mengingat fungsi sosial pasal 20 UUPA. Sifat kuat dan terpenuhi berarti yang paling kuat dan paling penuh, berarti pula bahwa pemegang hak milik atau pemilik tanah itu mempunyai hak untuk berbuat bebas, artinya boleh mengasingkan tanah miliknya kepada pihak lain dengan jalan menjualnya, menghibahkan, menukarkan dan mewariskannya. "Turun temurun" artinya hak milik atas tanah dapat berlangsung terus selama pemiliknya masih hidup dan bila pemiliknya sudah meninggal dunia, maka hak miliknya dapat dilanjutkan oleh ahli warisnya sepanjang memenuhi syarat sebagai subjek hak milik. "Terkuat", artinya hak milik atas tanah lebih kuat bila dibandingkan dengan hak atas tanah yang lain, tidak mempunyai batas waktu tertentu, mudah dipertahankan dari gangguan pihak lain dan tidak mudah dihapus. "Terpenuh", artinya hak milik atas tanah member wewenang kepada pemiliknya paling luas dibandingkan degan hak atas tanah yang lain, dapat menjdi induk bagi hak atas tanah yang lain, tidak berinduk pada hak atas tanah yang lain, dan penggunaan tanahnya lebih luas bila dibandingkan dengan hak atas tanah yang lain. Hak milik adalah hak untuk menikmati kegunaan sesuatu benda dengan leluasa dan untuk berniat bebas terhadap kebendaan itu, dengan kedaulatan sepenuhnya asal tidak bertentangan dengan undang-undang atau peraturan umum yang ditetapkan oleh suatu kekuasaan yang berhak menetapkannya, dan tidak mengganggu hak-hak orang lain (Soimin, 2004). Dengan dikuasainya suatu benda berdasarkan hak milik, maka seseorang pemegang hak milik diberikan kewenangan untuk meguasainya secara tenteram dan untuk mempertahankannya terhadap siapapun yang bermaksud untuk mengganggu ketenteramannya dalam menguasai, memanfaatkan serta mempergunakan benda tersebut. Pada dasarnya hak milik atas tanah hanya dapat dimiliki oleh warga negara Indonesia tunggal saja, dan tidak dapat dimiliki oleh warga negara asing dan badan hukum, baik yang didirikan di indonesia maupun yang didirikan diluar negeri dengan pengecualian badan-badan hukum tertentu yang diatur dalam Peraturan Pemerintah Nomor 38 Tahun 1963. Ini berarti sebagai warga Negara Indonesia tunggal, dan badan-badan yang ditunjuk dalam Peraturan Pemerintah Nomor 38 Tahun 1963. Terdiri dari (Muljadi \& Widjaja, 2008):

a. Bank-bank yang didirikan oleh negara (selanjutnya disebut Negara Bank);

b. Perkumpulan-perkumpulan Koperasi Pertanian yang didirikan berdasarkan Undang-Undang No. 79 Tahun 1958 (Lembaran Negara Tahun 1958 No. 139);

c. Badan-badan keagamaan, yang ditunjuk oleh Menteri Pertanian/ Agraria setelah mendengar Menteri Agama.

d. Badan-badan sosial yang ditunjuk oleh Menteri Pertanian/Agraria Setelah Mendengar Menteri Kesejahteraan Sosial.

2. Hak Guna Usaha;

Hak Guna Usaha dalam Pasal 28 Undang-Undang Nomor 5 Tahun 1960 tentang Peraturan Dasar Pokok-Pokok Agraria adalah hak untuk mengusahakan tanah yang dikuasai langsung oleh Negara, dalam jangka waktu sebagaimana tersebut dalam Pasal 29, guna perusahaan pertanian, perikanan atau peternakan. Menurut Pasal 29 pada undang-undang yang sama Hak Guna Usaha diberikan waktu paling lama 25 tahun atau untuk perusahaan tertentu dapat diberikan Hak Guna 
Usaha untuk paling lama 35 tahun (Ibid). Luas tanah Hak Guna Usaha adalah untuk perseorangan luasnya minimalnya 5 hektar dan maksimalnya 25 hektar. Sedangkan untuk badan hukum, luas minimalnya 5 hektar dan maksimalnya ditetapkan oleh kepala Badan Pertanahan Nasional (Pasal 28 ayat (2) Undang-Undang Nomor 5 Tahun 1960 Tentang Peraturan Dasar Pokok-Pokok Agraria Jo. Pasal 5 Peraturan Pemerintah Nomor 40 Tahun 1996) (Santoso, 2010). Pemberian Hak Atas Tanah berkaitan dengan subyek dan obyek serta proses yang terjadi dalam pemberian hak tersebut, termasuk pula pemberian Hak Guna Usaha (HGU). Menyangkut subyek Hak Guna Usaha (HGU) diatur dalam Pasal 2 Peraturan Pemerintah Nomor 40 Tahun 1996, dinyatakan bahwa yang dapat mempunyai Hak Guna Usaha adalah : Warga Negara Indonesia dan Badan Hukum yang didirikan menurut hukum Indonesia dan berkedudukan di Indonesia (Supriadi, 2010). Berakhirnya Hak Guna Usaha yaitu apabila : waktunya berakhir melanggar syarat pemberian, dilepas haknya, dicabut haknya untuk kepentingan umum, tanahnya musnah dan melanggar prinsip nasionalitas.

\section{Hak Guna Bangunan;}

Pengertian Hak Guna Bangunan (HGB) terdapat dalam Pasal 35 Undang-Undang Nomor 5 Tahun 1960 Tentang Peraturan Dasar Pokok-Pokok Agraria, yaitu : hak untuk mendirikan dan mempunyai bangunan atas tanah yang bukan miliknya sendiri, dengan jangka waktu paling lamanya 30 tahun dan dapat diperpanjang untuk jangka waktu paling lama 20 tahun (Santoso, 2010). Selain itu Hak Guna Bangunan (HGB) dapat beralih dan dialihkan kepada orang lain (Harsono, 1987). Subyek yang berhak mempunyai Hak Guna Bangunan terdapat dalam Pasal 36 Undang-Undang Nomor 5 Tahun 1960 Tentang Peraturan Dasar Pokok-Pokok Agraria Jo Pasal 19 Peraturan Pemerintah Nomor 40 Tahun 1996 yaitu: Warga Negara Indonesia dan Badan Hukum yang didirikan menurut hukum dan berkedudukan di Indonesia. Akan tetapi jika subyek Hak Guna Bangunan (HGB) tidak memenuhi syarat sebagai warga Negara Indonesia atau Badan Hukum Indonesia maka dalam 1 tahun wajib melepaskan atau mengalihkannya terhadap orang lain yang memenuhi syarat. Adapun jika hal ini tidak dilakukan hak guna bangunannya terhapus (Urip Santoso, 2012). Berakhirnya Hak Guna Bangunan (HGB) yaitu apabila : jangka waktunya berakhir, dihentikan sebelum jangka waktu berakhir, dilepas oleh pemegang hak, dicabut untuk kepentingan umum, diterlantarkan,

\section{Hak Pakai}

Hak pakai menurut pasal 41 UUPA hak yang diberikan Negara untuk digunakan dan atau memungut hasil dari tanah yang dikuasai langsung oleh Negara atau tanah milik orang lain yang memberi wewenang dan kewajiban yang ditentukan dalam keputusan pemberiannya oleh pejabat yang berwenang memberikannya atau dalam perjanjian dengan pemilik tanahnya yang bukan perjanjian sewa-menyewa atau perjanjian pengolahan tanahnya, segala sesuatu asal tidak bertentangan dengan asas dan ketentuan Undang-undang Pokok Agraria. Dalam hal misalnya bagi kedutaan-kedutaan dapat diberikan hak pakai, jadi pemakaian tanahnya bukan dalam rangka perjanjian sewa menyewa atau perjanjian pengolahan tanah dan lain sebagainya, hak pakai ini dapat berlaku sepanjang tanahnya dipergunakan untuk itu. Pemberian hak pakai dapat dengan cuma-cuma, dengan pembayaran atau pemberian jasa yang berupa apapun. Akan tetapi, tidak boleh diserati syarat-syarat yang mengandung unsur pemerasan. Yang dapat mempunyai hak pakai menurut pasal 39 PP. Nomor 40 Tahun 1996 Tentang Hak Guna Usaha, Hak Guna Bangunan Dan Hak Pakai Atas Tanah yaitu:

a. Warga Negara Indonesia;

b. Badan hukum yang didirikan menurut hukum Indonesia dan berkedudukan di Indonesia;

c. Departemen, Lembaga Pemerintah Non Departemen dan Pemerintah Daerah;

d. Badan-badan keagamaan dan sosial;

e. Badan hukum asing yang mempunyai perwakilan di Indonesia;

f. Perwakilan negara asing dan perwakilan badan Internasional.

Sejalan dengan hal tersebut apabila orang atau badan hukum yang dapat menguasai tanah dalam hak pakai tidak memenuhi syarat sebagaimana yang diatur dalam Pasal 39 ayat (1) diatas, maka 
wajib dalam satu tahun pemegang hak melepaskan atau mengalihkan hak itu pada pihak yang lain yang memenuhi syarat, jika tidak dilakukan maka hak tersebut akan terhapus. Tentang pengalihan hak pakai, menurut pasal 54 PP. Nomor 40 Tahun 1996 Tentang Hak Guna Usaha, Hak Guna Bangunan Dan Hak Pakai Atas Tanah sepanjang mengenai tanah yang langsung dikuasai pengalihannya kepada pihak lain haruslah seizin pejabat yang berwenang, sedang hak pakai atas tanah milik hanya dapat dialihkan kepada pihak lain, apabila memungkinkan dalam perjanjian yang bersangkutan dengan pemilik tanahnya. Berakhirnya Hak Pakai yaitu apabila : jangka waktu berakhir, tanah musnah, dicabut untuk kepentingan umum, diterlantarkan dan jika tidak dapat dipergunakan lagi kembali ke Negara

\section{Hak Pengelolaan}

Di dalam praktek dikenal pula adanya hak pengelolaan yang bersumber pada UUPA, dimana perumusan mengenai hak pengelolaan tersebut dituangkan dalam Peraturan Pemerintah Nomor 9 Tahun 1999 Tentang Tata Cara Pemberian dan Pembatalan Hak Atas Tanah Negara dan Hak Pengelolaan pasal 1 ayat (3) sebagai berikut: "Hak pengelolaan adalah hak menguasai dari negara yang kewenangannya sebagian dilimpahkan kepada pemegangnya" Tanah yang langsung dikuasai oleh negara yang memberi wewenang kepada pemegang haknya untuk:

a. Merencanakan peruntukan dan penggunaan tanah tersebut;

b. Menggunakan tanah tersebut untuk keperluan pelaksanaan tugasnya;

c. Menyerahkan bagian-bagian dari tanah itu kepada pihak ketiga menurut persyaratan yang ditentukan oleh prusahaan pemegang hak tersebut yang meliputi segi-segi peruntukan, penggunaan, jangka waktu pemberian hak atas tanah kepada pihak ketiga yang bersngkutan dilakukan oleh pejabat yang berwenang sesuai PMDN No. 6 Tahun 1972 jo. No. 5 Tahun 1973 dan perundang-undangan lainnya yang berlaku;

d. Menerima uang pemasukan dan/atau uang wajib tahunan".

Seperti dengan hak-hak atas tanah yang lain dimana hak-hak tersebut dapat habis karena sesuatu hal, maka hak pengelolaan juga habis karena:

1) Dilepaskan oleh pemegang haknya;

2) Dibatalkan karena tanahnya tidak dipergunakan sesuai pemberian haknya;

3) Dicabut oleh Negara untuk kepentingan umum;

4) Karena berakhir jangka waktunya.

Disamping penguasaan tanah negara dengan hak pengelolaan, dapat juga merupakan dasar untuk menyelenggarakan perusahaan tanah oleh daerahdaerah dan instansi-instansi lain. Pada umumnya tanah-tanah yang diberikan dengan hak pengelolaan itu merupakan tanah-tanah bangunan yang sudah dimatangkan sendiri oleh penerima hak.

\section{Legalitas Formal Hak Atas Tanah}

Persoalan mengenai Pertanahan saat ini mendapat perhatian yang khusus dari berbagai pihak. Sehubungan dengan hal tersebut, maka terhadap hak-hak atas yang dimiliki oleh orang perseorangan ataupun badan hukum harus memiliki jaminan kepastian hukum. Dalam rangka memberikan jaminan kepastian hukum yang merupakan salah satu tujuan pokok UUPA, maka Undang-Undang menginstruksikan kepada pemerintah untuk mengadakan legalitas formal di seluruh wilayah Indonesia yang bersifat Rechskadaster.

Bentuk legalitas formal terhadap hak atas tanah yaitu dengan cara melakukan pendaftran tanah. Terkait dengan pendaftaran tanah diatur dalam pasal 19 Undang-Undang Pokok Agraria. Sebagai landasan teknis pendaftaran tanah diatur dalam Peraturan Pemerintah No. 10 Tahun 1961 tantang pendaftaran tanah, kemudian disempurnakan dalam Peraturan Pemerintah No. 24 Tahun 1997. Pendaftaran tanah adalah suatu kegiatan administrasi yang dilakukan pemilik terhadap hak atas tanah, baik dalam pemindahan hak ataupun pemberian dan pengakuan hak baru, kegiatan pendaftaran tersebut memberikan suatu kejelasan status terhadap tanah.

Sedangkan pengertian Pendaftaran Tanah menurut Pasal 1 angka 1 PP No. 24 Tahun 1997 adalah "Rangkaian kegiatan yang dilakukan oleh Pemerintah secara terus menerus, 
berkesinambungan dan teratur, meliputi pengumpulan, pengolahan, pembukuan, dan penyajian serta pemeliharaan data fisik dan data yuridis, dalam bentuk peta dan daftar, mengenai bidang-bidang tanah dan satuan-satuan rumah susun, termasuk pemberian surat tanda bukti haknya bagi bidangbidang tanah yang sudah ada haknya dan hak milik atas satuan rumah susun serta hak-hak tertentu yang membebaninya.

Kata-kata "suatu rangkaian kegiatan" menunjuk kepada adanya berbagai kegiatan dalam penyelenggaraan pendaftaran tanah, yang berkaitan satu dengan yang lain, berturutan menjadi satu kesatuan rangkaian yang bermuara pada tersedianya data yang diperlukan dalam rangka memberikan jaminan kepastian hukum dibidang pertanahan bagi rakyat. Kata "terus menerus" menunjuk kepada pelaksanaan kegiatan, yang sekali dimulai tidak akan ada akhirnya. Data yang sudah terkumpul dan tersedia harus selalu dipelihara, dalam arti disesuaikan dengan perubahan perubahan yang terjadi kemudian, hingga tetap sesuai dengan keadaan terakhir. Kata "teratur" menunjukan, bahwa semua kegiatan harus berlandaskan peraturan perundang-undangan yang sesuai, karena hasilnya akan merupakan data bukti menurut hukum, biarpun daya kekuatan pembuktiannya tidak sulalu sama dalam hukum negara-negara yang menyelenggarakan pendaftaran tanah.

Salah satu tujuan dari pendaftaran tanah adalah memberikan kepastian hukum hak atas tanah yang dimiliki. Kepastian hukum hak atas tanah dapat diperoleh pemegang hak atas tanah dengan cara melakukan pendaftaran tanah. Pendaftaran tanah merupakan tugas negara yang dilaksanakan oleh pemerintah untuk kepentingan rakyat dalam rangka menjamin kepastian hukum di bidang pertanahan (Rahman et al., 2020). Sasaran dari kepastian hukum hak atas tanah adalah memberikan perlindungan hukum kepada pemegang hak atas tanah, (siapa pemiliknya, ada / tidak beban diatasnya) dan kepastian mengenai obyeknya, yaitu letaknya, batas-batasnya dan luasnya serta ada atau tidaknya bangunan, tanaman diatasnya (Effendie, 1993).

Menurut Sumardjono (1997), bahwa "terbitnya Peraturan Pemerintah Nomor 24 Tahun 1997 tentang Pendaftaran Tanah dilatar belakangi oleh kesadaran akan semakin pentingnya peran tanah dalam pembangunan yang semakin memerlukan dukungan kepastian hukum di bidang pertanahan. Secara normatif, Kepastian hukum itu memerlukan tersedianya perangkat peraturan perundangundangan yang secara operasional mampu mendukung pelaksanaannya. Secara empiris, keberadaan peraturan perundang-undangan itu perlu dilaksanakan secara konsisten dan konsekuen oleh sumber daya manusia pendukungnya (Sumardjono, 1997)."

Menurut Pasal 3 PP 24 Tahun 1997 tentang Pendaftaran Tanah menyebutkan bahwa pendaftaran tanah di Indonesia bertujuan untuk (Sale et al., 2010):

1. Memberikan kepastian hukum dan perlidungan hukum kepada pemegang hak atas suatu bidang tanah.

2. Menyediakan informasi-informasi kepada pihak-pihak yang berkepentingan dan;

3. Untuk terjadinya tertib administrasi pertanahan.

Dalam penjelasan pasal diatas bahwa kepastian hukum merupakan tujuan utama diselenggarakannya pendaftaran tanah sebagaimana diperintahkan oleh Pasal 19 UUPA. Dengan tujuan pendaftaran tanah adalah menjamin kepastian hukum hak-hak atas tanah, jaminan hukum hakhak atas tanah meliputi:

a. Kepastian hukum atas obyek bidang tanahnya, yaitu letak bidang tanah, letak batas-batas dan luasnya (obyek hak).

b. Kepastian atas subyek haknya, yaitu siapa yang menjadi pemiliknya (subyek hak) dan;

c. Kepastian hukum atas jenis hak atas tanahnya.

Kepastian hukum obyek dan subyek hak sangat diperlukan dalam lalu lintas hukum mengenai hak-hak atas tanah, sehingga oleh pemerintah diselenggarakan suatu sistem keterbukaan/pengumuman mengenai hak atas tanah atau sistem publisitas. Publisitas berarti prinsip dimana setiap orang dapat mengetahui semua hak-hak atas tanah dan semua perbuatan hukum mengenai tanah. Untuk menjamin kepastian hukum hak-hak atas tanah, maka pendaftaran tanah harus meliputi (Harsono, 2007): 
1) Kadaster hak yaitu kegiatan pengukuran dan pemetaan bidang-bidang tanah hak dan pendaftaran bidang-bidang tersebut dalam daftar-daftar tanah. Bidang-bidang tanah hak adalah bidangbidang yang dimiliki orang atau badan hukum dengan suatu hak.

2) Pendaftaran hak yaitu kegiatan pendaftaran hak-hak dalam daftar buku tanah atas pemegang haknya.

\section{Sertifikat Sebagai Bukti Legalitas Formal Hak Atas Tanah}

Bentuk legalitas formal terhadap hak atas tanah adalah dengan cara melakukan pendaftaran tanah. Pendaftaran tanah bertujuan untuk mewujudkan adanya kepastian hukum terhadap pemegang hak atas tanah di seluruh wilayah Republik Indonesia. akibat hukum dari pendaftaran terhadap hak atas tanah yaitu diberikannya surat tanda bukti yang lazim disebut sertifikat hak atas tanah. Menurut Peraturan Pemerintah Nomor 24 Tahun 1997 tentang Pendaftaran Tanah, sertifikat adalah surat tanda bukti hak sebagaimana dimaksudkan dalam Pasal 19 ayat (2) huruf c yang memuat data yuridis maupun data fisik obyek yang didaftarkan untuk hak atas tanah, hak pengelolaan, tanah wakaf, hak milik atas satuan rumah susun dan hak tanggungan yang masing-masing sudah dibukukan dalam buku tanah. Data yuridis diambil dalam buku tanah sedangkan data fisik diambil dari surat ukur.

Sehubungan dengan hal tersebut dapat diketahui bahwa sertifikat merupakan surat tanda bukti hak yang kuat mengenai data fisik data-data yuridis yang termuat di dalamnya. Sehingga data fisik dan data yuridis tersebut sesuai dengan data yang ada dalam surat ukur dan buku tanah yang bersangkutan. Jadi salinan buku tanah (berisi data yuridis yang mencakup keterangan mengenai data yuridis mengenai haknya-haknya apa, siapa pemegang haknya, ada atau tidak adanya hak pihak lain) dan surat ukur (berisi data fisik mengenai tanahnya lokasinya, batas-batasnya, luasnya bangunan dan tanaman yang ada di atasnya), kemudian dijilid menjadi satu dan diberi sampul disebut sertifikat hak atas tanah, yang kemudian diserahkan kepada pemegang hak sebagai alat bukti yang kuat (Pasal 19 ayat (2) huruf c dan Pasal 32 ayat (1) Peraturan Pemerintah Nomor 24 Tahun 1997 tentang Pendaftaran Tanah). Sertifikat sebagai tanda bukti yang kuat, dalam arti bahwa selama tidak dapat dibuktikan sebaliknya data fisik dan data yuridis yang tercantum di dalamnya harus diterima sebagai data yang benar baik dalam melakukan perbuatan hukum sehari hari maupun dalam berperkara di pengadilan.

Sehubungan dengan hal tersebut dapat dipahami bahwa sertifikat tidak mempunyai kekuatan bukti yang mutlak, karena masih memungkinkan untuk dinyatakan batal atau dinyatakan tidak mempunyai kekuatan hukum melalui putusan pengadilan. Pihak yang berkepentingan dapat mengajukan gugatan ke pengadilan untuk meminta pengadilan agar memutuskan bahwa suatu sertifikat hak atas tanah tertentu tidak mempunyai kekuatan hukum. Berdasarkan PP No. 24 Tahhun 1997 menyatakan bahwa seseorang atau badan hukum tidak dapat mengajukan gugatan terhadap suatu sertifikat apabila telah lewat waktu tertentu dan telah memenuhi persyaratan sebagaimana ditentukan dalam Pasal 32 ayat (2). Pasal 32 ayat (2) PP No. 24 Tahun 1997 menyebutkan:

"Dalam hal atas suatu bidang tanah sudah diterbitkan sertifikat secara sah atas nama orang atau badan hukum yang memperoleh tanah tersebut dengan itikad baik dan secara nyata menguasainya, maka pihak lain yang merasa mempunyai hak atas tanah itu tidak dapat lagi menuntut pelaksanaan hak tersebut apabila dalam waktu 5 (lima) tahun sejak diterbitkannya sertifikat itu tidak mengajukan keberatan secara tertulis kepada pemegang sertifikat dan Kepala Kantor Pertanahan yang bersangkutan ataupun tidak mengajukan gugatan ke Pengadilan mengenai penguasaan tanah atau penerbitan sertifikat tersebut."

Berdasarkan ketentuan tersbut dapat dipahami bahwa batas waktu 5 (lima) tahun itu berlaku apabila memenuhi 3 (tiga) persyaratan, yaitu (Ismail , 2011):

1. Pelaksanaan pendaftaran tanah yang melahirkan sertifikat tersebut dilakukan secara sah, artinya sesuai dengan ketentuan perundang-undangan yang berlaku, sebagai contoh bahwa salah satu tahapan dalam pelaksanaan pendaftaran tanah adalah dilakukan pengumuman terhadap data tanah yang telah diteliti sebelum dilakukan pembukuan hak atas tanah. Apabila pengumuman tidak 
dilakukan atau dilakukan tidak sesuai dengan aturan atau menyimpang dari tujuan diadakan pengumuman maka hal itu dapat dikategorikan sebagai cacat hukum dalam proses pensertifikatan;

2. Penguasaan tanah oleh pemohon atau penerusnya dilakukan dengan iktikat baik, hal ini tentu ada ukuran-ukuran dalam hukum mengenai iktikat baik tersebut; dan

3. Tanah tersebut dikuasai secara nyata oleh pemohon, hal ini berarti tidak cukup penguasaan secara hukum saja.

Dengan demikian apabila ketiga persyaratan tersebut tidak dipenuhi secara kumulatif maka batasan waktu 5 (lima) tahun tersebut tidak dapat diterapkan.

Sertifikat diterbitkan untuk kepentingan pemegang hak yang bersangkutan sesuai dengan data fisik dan data yuridis yang telah didaftar dalam buku tanah. Sertifikat hanya boleh diserahkan kepada pihak yang namanya tercantum dalam buku tanah yang bersangkutan sebagai pemegang hak atau kepada pihak lain yang dikuasakan olehnya. Sertifikat yang diberikan kepada pemegang hak yang bertikad baik akan memperoleh perlindungan hukum secara preventif sebagaiman yang telah di atur dalam ketentuan pasal 32 ayat 1 dan ayat 2 Peraturan Pemerintah Nomor 24 Tahun 1997 tentang Pendaftaran Tanah dan perlindungan hukum secara represif yakni dengan adanya lembaga Rechstverwerking (Kusuma et al., 2017).

Pemberian tanda bukti hak untuk pendaftaran tanah berupa sertifikat juga memiliki beberapa fungsi yaitu (Kusuma, 2017):

1. Fungsi yuridis dimana sertifikat menjadi dokumen yang dapat digunakan oleh pemegang hak atas tanah untuk membuktikan haknya sebagai alat bukti yang kuat dan memberikan kepastian hukum hak atas tanahnya.

2. Fungsi secara psikologis adalah sertifikat dapat memberikan ketenanganan, rasa aman dan rasa nyaman kepada para pemilik pemegang hak atas tanah yang dimana namanya tertulis disertifikat hak atas tanah dan tercatat dalam buku tanah dikantor Pertanahan nasional.

3. Dengan adanya sertifikat para pemilik hak atas tanah dapat mengetahui secara pasti dan tercatat dalam Peta Bidang tanah atau Gambar situasi batas-batas tanah tersebut dan gambaran yang jelas bentuk dan luas tanahnya secara jelas.

4. Fungsi secara ekonomis yaitu sertifikat hak tersebut dapat digunakan sebagai jaminan di bank yang dalam rangka memenuhi kebutuhan dari pemegang hak atas tanah tersebut.

\section{KESIMPULAN DAN SARAN}

\section{Kesimpulan}

Dari uraian yang telah kami paparkan di atas, maka dapat kami simpulkan bahwa: sosialisasi (penyuluhan hukum) dibidang pertanahan sangat diperlukan oleh masyarakat pedesaan, hal ini terbukti dari hasil diskusi kami dengan anggota masyarakat di lokasi penyuluhan, bahwa informasiinformasi yang menyangkut hukum pertanahan sangat mereka perlukan, terutama sekali informasi tentang pentingnya melakukan legalitas formal terhadap hak atas tanah yang mereka miliki. Sehingga dengan dilakukannya kegiatan sosialisasi tersebut dapat menambah informasi, merubah pola pikir dan sikap masyarakat desa senteluk akan pentingnya melakukan kegiatan legalitas formal terhadap hak atas tanah yang dimilikinya.

Saran

Sosialisasi hukum melalui kegiatan penyuluhan hukum tetap dilaksanakan secara terus menerus dengan materi yang disesuaikan dengan situasi dan kebutuhan masyarakat setempat, terutama yang berkaitan dengan peraturan perundang-undangan yang terbaru.

\section{DAFTAR PUSTAKA}

Dewandaru, P. A., Hastuti, N. T., \& Wisnaeni, F. (2020). Penyelesaian Sengketa Tanah Terhadap Sertifikat Ganda Di Badan Pertanahan Nasional. Jurnal Notarius, 3(1).

Effendie, B. (1993). Pendaftaran Tanah di Indonesia dan Peraturan-Perturan Pelaksaanya. Bandung : Alumni

Harsono, B. (1987). Hukum Agraria Indonesia. Jakarta: Djambatan. 
Harsono, B. (2003). Hukum Agraria Indonesia, Sejarah Pembentukan Undang-Undang Pokok Agraria, Isi dan Pelaksanaannya. Jakarta : Djambatan.

Harsono, B. (2007). Hukum Agraria Indonesia. Jakarta: Djambatan.

Hutagalung, A. S. (2005). Tebaran Pemikiran Seputar Masalah Hukum Tanah. Jakarta : Lembaga Pemberdayaan Hukum Indonesia.

Ismail, I. (2011). Sertifikat Sebagai alat Bukti Hak Atas Tanah Dalam Proses Peradilan. Kanun Jurnal IImu Hukum No. 53 Th XIII

Kusuma, D. A. (2017). Hak Milik Atas Tanah Sebagai Alat Bukti Yang Kuat. Tesis: Magister Kenotarian Universitas Mataram,

Kusuma, D. A., Rodliyah, \& Sahnan. (2017). Sertifikat Hak Milik Atas Tanah Sebagai Alat Bukti Yang Kuat. Jurnal ius, 5 (2).

Marwa \& Dinata, M. (2020). Pelatihan Penulisan Artikel Ilmiah dan Publikasi di Jurnal bagi Guru SMAN 4 Tualang, Kabupaten Siak. Jurnal Pengabdian Kepada Masyarakat. Volume 5 Nomor 1.

Muljadi K., \& Widjaja, G. (2008). "Hak-hak Atas Tanah". Jakarta: Kencana Prenada Media Group.

Peraturan Pemerintah No. 24 tahun 1997 Tentang Pendaftaran Tanah. 8 Juli 1997. Lembaran Negara Republik Indonesia tahun 1997 No. 59. Jakarta.

Peraturan Pemerintah Nomor 38 Tahun 1963 Tentang Penunjukan Badan-Badan Hukum yang Dapat Mempunyai Hak Milik Atas Tanah. 19 Juni 1963. Lembaran Negara Republik Indonesia tahun 1963 No. 61. Jakarta.

Peraturan Pemerintah Nomor 40 Tahun 1996 Tentang Hak Guna Usaha, Hak Guna Bangunan Dan Hak Pakai Atas Tanah. 17 Juni 1996. Lembaran Negara Republik Indonesia Tahun 1996 Nomor 58. Jakarta.

Peraturan Pemerintah Nomor 9 Tahun 1999 Tentang Tata Cara Pemberian dan Pembatalan Hak Atas Tanah Negara dan Hak Pengelolaan. 24 Oktober 1999. Lembaran Negara Republik Indonesia tahun 1999. Jakarta.

Prakosa, D., \& Purwanto, B. A. (1985). Eksistensi Prona Sebagai Pelaksana Mekanisme Fungsi Agraria. Jakarta : Ghalia Indonesia.

Rahman, A., Asyhadie, Z., Andriyani, S., \& Mulada, D. A.. (2020). Pendaftaran Tanah Warisan Yang Belum Dibagi Waris. Jurnal Kompilasi Hukum, 5 (1).

Sale, A., Saleng, A., Suriyaman, A., Pide, M., Patittingi, F., Nur, S. S., \& Lahae, K. (2010). Bahan Ajar Hukum Agraria. Makassar : AS Publishing.

Santoso, U. (2010). Hukum Agraria \& Hak-Hak Atas Tanah. Jakarta: Kencana Prenada Media Group.

Santoso, U. (2012). Hukum Agraria Komprehensif. Jakarta: Kencana Prenada Media Group.

Setiabudi, J. (2013). Panduan Lengkap Mengurus Tanah Rumah Serta Segala Perizinannya. Yogyakarta : Buku Pintar.

Soerodjo, I. (2002). Kepastian Hukum Hak Atas Tanah di Indonesia. Surabaya: Arkola Surabaya.

Soimin, S. (2004). Status Hak dan Pembebasan Tanah. Jakarta: Sinar Grafika.

Sumardjono, M. S. W. 1997. Kepastian Hukum dan Perlindungan Hukum Dalam Pendaftaran Tanah. Seminar Nasional Kebijakan Baru Pendaftaran Tanah dan Pajak-pajak yang terkait : Suatu Proses sosialisasi dan Tantangannya. Yogyakarta.

Supriadi. (2020). Hukum Agraria. Jakarta: Sinar Grafika.

Undang-Undang Republik Indonesia Nomor 5 Tahun 1960 Tentang Peraturan Dasar Pokok Agraria. 24 September 1960. Lembaran Negara Republik Indonesia Tahun 1960 Nomor 104. Jakarta. 